\title{
Zasoby lokalne, odnowa wsi i koncepcje rozwoju obszarów wiejskich. Próba teoretycznego ujęcia zależności
}

\section{Local resources, village renewal and rural development concepts. An attempt to theoretical view on relations}

\author{
Oskar WOLSKI ${ }^{1,3} \bullet$ Łukasz SYKAŁA ${ }^{2,3}$ \\ ${ }^{1}$ Uniwersytet Łódzki \\ Wydział Nauk Geograficznych, Katedra Geografii Regionalnej i Społecznej \\ ul. Narutowicza 88, 90-139 Łódź \\ oskwolski@gmail.com \\ ${ }^{2}$ Uniwersytet Jagielloński \\ Instytut Geografii i Gospodarski Przestrzennej \\ ul. Gronostajowa 7, 30-387 Kraków \\ lukasz.sykala@uj.edu.pl \\ ${ }^{3}$ Instytut Rozwoju Miast \\ Zakład Badań Procesów Rozwojowych w Europie Środkowo-Wschodniej \\ ul. Cieszyńska 2, 30-015 Kraków
}

Zarys treści: Odnowa wsi jest coraz silniej akcentowanym elementem przemian przestrzeni wiejskiej, zarówno w wymiarze praktycznym, jak i naukowym. To, jak zmieniała się odnowa wsi warunkowane było zmianą podejścia do koncepcji rozwoju obszarów wiejskich i różnej roli zasobów lokalnych w tych koncepcjach. Na powyższe zależności nakłada się wykorzystanie tych zasobów w działaniach z zakresu odnowy wsi. W związku z powyższym te trzy zagadnienia, tj. odnowa wsi, rozwój obszarów wiejskich i zasoby lokalne silnie ze sobą korespondują.

Głównym celem pracy jest ukazanie zakorzenienia odnowy wsi w paradygmatach/koncepcjach rozwoju obszarów wiejskich, a częściowo także rozwoju regionalnego/lokalnego i w innych koncepcjach naukowych oraz ukazanie roli zasobów lokalnych w odnowie wsi na przestrzeni lat. Artykuł ma charakter teoretyczno-dyskusyjny i opiera się na studiach literatury przedmiotu. Zawarte w pracy rozważania wskazują, że odnowa wsi bazuje na zasobach lokalnych obszaru, które jednocześnie wzmacnia. Zasoby lokalne uznawane są także za kluczowe z perspektywy rozwoju regionalnego/lokalnego. Jednocześnie różne było ich postrzeganie w kontekście zmian koncepcji rozwoju obszarów wiejskich. W świetle współczesnych koncepcji naukowych o wykorzystaniu tych zasobów powinna decydować społeczność lokalna, w tym z wykorzystaniem instrumentów zewnętrznych.

Słowa kluczowe: zasoby lokalne, odnowa wsi, rozwój obszarów wiejskich, koncepcje rozwoju obszarów wiejskich. 


\section{Wstęp}

Odnowa wsi w Polsce, pomimo swojej krótkiej tradycji, staje się coraz silniej akcentowanym elementem rozwoju obszarów wiejskich zarówno na poziomie lokalnym, regionalnym, krajowym, jak i europejskim. Na poziomie lokalnym odnowa może być realizowana jako oddolna inicjatywa w sołectwie lub działanie własne gminy, przy wsparciu funduszu sołeckiego lub funduszu celowego z budżetu gminy, a także innych środków finansowych przewidzianych na ten cel w budżecie gminy ${ }^{1}$. Na poziomie regionalnym może znajdować się w wojewódzkich programach odnowy wsi, które posiadają własny i różny w zależności od województwa mechanizm finansowania. Na szczeblu krajowym zaś jej realizacja jest możliwa dzięki Ustawie z dnia 9 października 2015 r. o rewitalizacji. Na poziomie europejskim, czy też z wykorzystaniem funduszy europejskich, odnowa wsi mogła być realizowana zarówno w minionym okresie programowania (Program Rozwoju Obszarów Wiejskich na lata 2007-2013, działanie Odnowa i rozwój wsi), jak i w obecnej perspektywie budżetowej (Program Rozwoju Obszarów Wiejskich na lata 2014-2020, działanie Podstawowe usługi i odnowa wsi na obszarach wiejskich). Dodatkowo w innych programach operacyjnych współfinansowanych ze środków europejskich (np. Program Operacyjny Zrównoważony rozwój sektora rybołówstwa i nadbrzeżnych obszarów rybackich 2007-2013 czy też Regionalne Programy Operacyjne niektórych województw) również istniała możliwość realizacji działań z zakresu odnowy, choć ich charakter należy uznać w większości za typowo infrastrukturalny.

Odnowa wsi, choć stanowi raczej zespół działań praktycznych aniżeli samodzielną teorię rozwoju wsi, czerpie z dorobku i wiedzy różnych nauk. Z perspektywy socjologicznej oparta jest o założenia community development, idei wywodzącej się ze Stanów Zjednoczonych, mającej na celu rozwój i aktywizację społeczności lokalnych (Kaleta 2007). W geograficznym zaś ujęciu odnowa wsi nawiązuje do koncepcji czy też paradygmatów rozwoju obszarów wiejskich. Przede wszystkim rozpatrywano jej związek z modernizacją rolnictwa i tkanki urbanistycznej wsi, funkcjami wsi oraz jej rolę w rozwoju wsi w sensie ogólnym (np. Wilson 1999; Chigbu 2012). Takie podejście zauważalne było głównie jako rezultat wdrażania programów odnowy wsi w Europie, a zwłaszcza w Niemczech (Wolski 2016), co stanowi także oś główną naszych rozważań ${ }^{2}$ To sprzężenie nauki (koncepcje rozwoju obszarów wiejskich i innych koncepcji rozwoju społecznego) i praktyki (głównie opisy doświadczeń) w odnowie wsi zauważalne jest od lat 70. XX w. Od samego właściwie początku dyskutowano także rolę zasobów lokalnych w odnowie, które tej odnowie rzeczywiście podlegały. Na dobre odnowa zadomowiła się w kanonie badań geografii wsi na początku obecnego stulecia (Woods 2005).

Celem głównym pracy jest określenie zakorzenienia odnowy wsi w koncepcjach rozwoju obszarów wiejskich, a częściowo także rozwoju regionalnego/lokalnego i innych

\footnotetext{
${ }_{1}$ Należy przy tym pamiętać, że drobne lub niematerialne przedsięwzięcia, a także pewne inicjatywy dotyczące najbliższej mieszkańcom przestrzeni (w tym prywatnej) i jej otoczenia mogą być realizowane bez wsparcia finansowego.

2 Niemcy to kraj z najdłuższą tradycją tych działań w Europie, stąd niemiecka odnowa wsi ukazuje całą paletę zjawisk, które są w niej obecne. Począwszy od działań zupełnie podstawowych na rzecz infrastruktury, skończywszy na działaniach na rzecz rozwoju duchowego mieszkańców wsi. Z tego też powodu działania dotąd podejmowane w Niemczech stanowią najbardziej reprezentatywny przykład realizacji odnowy wsi. Co więcej, niemiecki model odnowy próbowano i wciąż próbuje przenieść na grunt polski, co zauważalne jest w wojewódzkich programach odnowy wsi. Stąd dla przejrzystości artykułu zdecydowano się odwołać głównie do założeń niemieckiej odnowy i prześledzić zmiany w jej modelu.
} 
koncepcjach naukowych obecnych w badaniach obszarów wiejskich oraz ukazanie roli zasobów lokalnych w odnowie i rozwoju obszarów wiejskich. Podjęcie tego zagadnienia na poziomie teoretycznym wynika z dostrzeżonych zależności i braków w opisie stanu wiedzy. Otóż odnowa wsi zmieniała się w relacji do zmian koncepcji rozwoju obszarów wiejskich. Podobnie na przestrzeni lat różna była rola zasobów lokalnych w tych koncepcjach. W związku z tym, że odnowa opiera się na zasobach lokalnych wsi, różnie postrzegano te zasoby w samych procesach odnowy. Nie ulega wątpliwości, że wskazane trzy zagadnienia, tj. odnowa wsi, rozwój obszarów wiejskich i zasoby lokalne silnie ze sobą korespondują. Dotychczas brakowało jednak syntetycznego opisu tych zależności, a wiedza dotycząca odnowy wsi wciąż nie jest w Polsce dostatecznie opisana. Stąd autorzy podjęli próbę uporządkowania i syntezy dotychczasowego stanu wiedzy wspólnego dla tych zagadnień.

Artykuł ma charakter teoretyczno-dyskusyjny. Jesteśmy świadomi, że nie wyczerpuje i nie prezentuje całości wiedzy na temat odnowy wsi, jednak z perspektywy celu głównego pracy nie było to konieczne. W artykule przestawiono definicje pojęć i sposób ich definiowania przez autorów, co dotyczy odnowy wsi, rozwoju, w tym rozwoju regionalnego/lokalnego, pojęcia zasobu i zasobu lokalnego oraz rewitalizacji. Zaprezentowano także zmiany historycznych etapów odnowy wsi na tle zmian koncepcji rozwoju obszarów wiejskich oraz rolę zasobów lokalnych w odnowie wsi. W podsumowaniu zawarto także pytania, których pogłębienie nie jest celem artykułu, lecz które powinny stanowić refleksję czytelnika na temat kształtowania rozwoju obszarów wiejskich i procesów odnowy wsi - obu z wykorzystaniem zasobów lokalnych.

\section{Operacjonalizacja pojęć rozwoju i odnowy wsi}

Pojęcie rozwoju, czego można się spodziewać, nie ma jednej definicji i może być bardzo różnie rozumiane. Najbardziej ogólna definicja została zaproponowana przez B. Domańskiego (2004, s. 7-8). Zgodnie z nią rozwój to „długotrwały proces zmian mających pewien kierunek". Równocześnie cytowany autor wskazuje, że jest to proces immanentny lub celowe działanie władz publicznych. W kategoriach zmiany struktury, także podkreślając kierunkowość tych zmian, pojęcie rozwoju definiuje Z. Chojnicki (1999, s. 269): „Rozwój jest ciągiem zmian ukierunkowanych i nieodwracalnych dokonujących się w strukturze obiektów złożonych, tj. systemów". Odnosząc tę definicję do rozważań na temat odnowy wsi można stwierdzić, że takim obiektem złożonym jest właśnie wieś. Jej struktura to system relacji budujący obecne w niej powiązania. Zmiana jest natomiast przejściem z pierwotnego stanu w inny, który w kategoriach ilościowych i jakościowych zachodzić może w efekcie realizowanej odnowy. Interesujący pogląd wyraził także K. Gorlach (2004). Jego zdaniem rozwój zawiera w sobie takie idee, jak odkrywanie czy ujawnianie, które autor utożsamia z pewnymi możliwościami i celami, które społeczność chce osiągnąć. Warto tutaj dodać, że także i w samej odnowie wsi dokonuje się pewne odkrycie na nowo - wartości wsi i wartości jej obszaru (np. Magel 1991).

Z perspektywy rozwoju regionalnego należy podkreślić fakt, że obszary wiejskie w klasycznych teoriach rozwoju nie są postrzegane jako jego motory. Odwrotnie, taką rolę przypisuje się obszarom miejskim, co jest wprost wskazywane w klasycznych koncepcjach rozwoju regionalnego. Taki postulat wyrażała koncepcja biegunów wzrostu Perroux/Boudeville'a, teoria kumulatywnej przyczynowości Myrdala, teorie Thompsona (1968) 
i Preda (1977) oraz model centrum i peryferii Friedmanna (na podstawie: Dawkins 2003; Grosse 2002). Z perspektywy wsi można więc stwierdzić, że w ówczesnych modelach rozwoju regionalnego siły sprawcze (motory) rozwoju obszarów wiejskich ulokowane były na zewnątrz.

Przenosząc rozważania na poziom lokalny, należy podjąć próbę zrozumienia specyfiki rozwoju w tej skali. Podobnie jak w przypadku pojęcia rozwoju w ogóle, rozwój lokalny nie ma jednej, spójnej definicji. Według J. Chądzyńskiego (2012, s. 69) funkcjonuje najczęściej wraz z takimi pojęciami, jak: lokalny, lokalność, społeczność lokalna, lokalne zasoby czy też układy lokalne bądź lokalne systemy. Słownik Języka Polskiego PWN (2016) wskazuje, że lokalny, to nic innego, jak ograniczony do danego miejsca, właściwy jemu. Ten powszechny sposób myślenia wyraża się choćby w definicji rozwoju lokalnego zaproponowanej przez J. Szewczuka (2011, s. 21), która podkreśla rolę mikroskali, w jakiej zachodzi. „Rozwój lokalny często jest interpretowany jako szczególny proces, który dotyczy ważkich zmian zachodzących w gminie, powiecie lub, inaczej, w mikroregionie, tj. lokalnym układzie społeczno-terytorialnym. Ten wyodrębniony z otoczenia układ charakteryzuje się na ogół specjalnymi cechami przestrzeni, gospodarki i kultury, a także specyficzną dla danego regionu hierarchią potrzeb i wartości" [wyróżnienia w tekście pochodzą od autorów]. Można zatem wyprowadzić wniosek, że rozwój lokalny to rozwój w skali lokalnej.

Definiując pojęcie odnowy wsi, należy podkreślić różnorodność jej znaczeń, która ma dwojakie przyczyny. Po pierwsze, z uwagi na różny stopień zaawansowania programów czy działań z zakresu odnowy wsi w zależności od kraju, czy nawet regionu (wewnątrz kraju) istnieją wyraźne różnice w sposobie interpretacji tych działań na gruncie praktycznym jako komponentu działań na rzecz rozwoju obszarów wiejskich. Po drugie, ze względu na regionalny charakter dotychczasowych badań poświęconych odnowie i różne ich zakorzenienie teoretyczne, także odmienne są podejścia w interpretacji odnowy wsi jako pewnego konstruktu teoretyczno-pojęciowego. W konsekwencji odnową wsi zwykło nazywać się nie tylko działania, które wydają się rzeczywiście zbieżne z jej celami w świetle literatury naukowej i dotychczas przeprowadzonych studiów empirycznych, podkreślających społeczno-kulturowy kontekst działań. Tak nazywane są także działania podstawowe i na rzecz infrastruktury, które wydają się dalekie od celów, jakie powinny być stawiane odnowie wsi, a wpisujące się jedynie w szablon definicji niezbędny do pozyskania zewnętrznego finansowania projektów.

Niemniej postrzeganie odnowy wsi jest w przewadze praktyczne, na co wskazuje choćby R. Kamiński (2007), twierdząc, że stanowi ona pewne podejście do rozwiązywania problemów wsi. W istocie odnowa wsi w Niemczech, gdzie w największym stopniu i z największym powodzeniem realizowana jest ona jako program w ramach polityki rozwoju obszarów wiejskich, została także zainicjowana w odpowiedzi na dostrzeżone problemy (Wolski 2016). W literaturze niemieckiej znaleźć można ponadto takie określenia odwołujące się do odnowy wsi, jak np. narzędzie rozwoju społecznego i ekonomicznego obszarów wiejskich (Schopen 2001; Chigbu 2012) czy kluczowa polityka rozwoju obszarów wiejskich (Wilson 1999). Jeśli, cytując za R.Wilczyńskim (2003, s. 12): „Odnowa wsi jest (...) koncepcją rozwoju obszarów wiejskich w formie najbardziej odpowiadającej społeczności lokalnej i przez nią samą wybranej", to nie ulega wątpliwości, że to narzędzie czy ta polityka ma charakter lokalny.

Społeczny charakter odnowy wsi, jak i jej lokalność, wyrażone zostały także u źródła idei programu odnowy wsi, bo w niemieckim ustawodawstwie. W Ustawie o scalaniu 
gruntów Republiki Federalnej Niemiec z 1994 r. (rozdział 2 i 3) znajdujemy zapis: „Jej [odnowy wsi - autorzy] lokalne cele różnią się miedzy gminami lub regionami - w zależności od tego, co tworzy największą potrzebę lub wizję. (...) Społeczność wiejska jest w centrum procesów odnowy wsi" (Chigbu 2012, s. 211).

Wspomniane zróżnicowanie celów odnowy wsi na szczeblu lokalnym i regionalnym jest zbieżne z tym, co zauważa B. Domański (2004, s. 13), a mianowicie że „w krytyce pojęcia rozwoju zwraca się uwagę na pomijanie lub niedocenianie znaczenia tego, co regionalne i lokalne". Tak więc rozwój zachodzi od poziomu lokalnego, na którym zmiany stanowią fundament zmian w szerszych skalach przestrzennych.

\section{Koncepcje rozwoju obszarów wiejskich a etapy historyczne odnowy wsi}

Odwołując się do koncepcji rozwoju obszarów wiejskich, należy wyjść od zakorzenienia współczesnej odnowy wsi w paradygmacie rewitalizacyjnym. Rewitalizację rozumiemy jako „ożywienie” obszaru, podtrzymanie lub przywrócenie mu jego własnych cech i funkcji - w tym w sferze pozamaterialnej. Paradygmat rewitalizacyjny wskazuje na długotrwały proces rozwoju w oparciu o lokalne zasoby. W tym sposobie myślenia o rozwoju wiejskiej przestrzeni zachodzi, i najpełniej się wyraża, sprzężenie wymienionych w tytule pracy: zasobów lokalnych, odnowy wsi i rozwoju obszarów wiejskich. Można zatem stwierdzić, że rewitalizacja tworzy pewien parasol rozpostarty nad wszystkimi tymi pojęciami.

Jednakże paradygmat rewitalizacyjny i będący jego pokłosiem przedstawiony sposób ujmowania rozwoju wsi to zakończenie pewnej drogi - ewolucji tak koncepcji rozwoju obszarów wiejskich (częściowo), jak i koncepcji odnowy wsi. Niezależnie od etapów, na których się znajdowała, odnowa wsi okazywała się inspirować i być organizowana ${ }^{3}$ zgodnie z obowiązującym postrzeganiem rozwoju obszarów wiejskich. Co istotne, miało to miejsce niezależnie od tego, jaki dominował sposób kształtowania rozwoju obszarów wiejskich, tzn. niezależnie od specyfiki ówczesnych koncepcji. Jeżeli więc zmieniał się charakter paradygmatów/koncepcji rozwoju obszarów wiejskich i pojawiały się kolejne koncepcje naukowe wyjaśniające zjawiska zachodzące w przestrzeni wiejskiej, zmieniała się też odnowa wsi i cechy działań z jej zakresu. Przyjąwszy więc założenie, że koncepcje rozwoju odpowiadają pewnym, mającym faktyczne miejsce zjawiskom, należy stwierdzić, że i odnowa odpowiadała pewnym wyzwaniom rozwojowym, przed jakim stawała wieś w różnych momentach czasowych.

To sprzężenie odnowy wsi z rozwojem obszarów wiejskich uwidacznia się bardziej, gdy prześledzi się zmiany koncepcji rozwoju obszarów wiejskich i zmiany „wewnętrznych paradygmatów" odnowy wsi w kolejnych etapach jej historii. Odnowa wsi swoją tradycją sięga do lat 50. ubiegłego stulecia, kiedy to zrodziła się w Zachodnich Niemczech (Wilson 1999; Wilczyński i Idziak 2013) ${ }^{4}$. Początkowo była utożsamiana z modernizacją, która rozpoczęła się w latach 50 . XX w. w Niemczech i trwała do połowy lat 70. Polegała ona głównie na wsparciu rolnictwa, zwiększaniu potencjału produkcyjnego wsi i rozwoju przemysłu rolniczego (Wilczyński i Idziak 2013). Odwołuje się ona do powszechnego w tym okresie postrzegania industrializacji i mechanizacji jako motoru napędowego rozwoju go-

\footnotetext{
3 Ponownie mowa o Niemczech.

${ }^{4}$ Z uwagi na objętość pracy pomięto opis celów programu. Został on ujęty, na różnych etapach realizacji programu odnowy, m.in. w pracach O.J. Wilson (1999) i G. Henkela (2000).
} 
spodarczego. Poprzez odnowę wsi dążono zatem do zwiększenia jej bazy ekonomicznej. Warto także podkreślić, że w tym okresie w studiach geograficznych za funkcję podstawową obszaru uznawano de facto dominujący zespół cech jego gospodarki (Wójcik 2012), co w przypadku obszarów wiejskich tożsame było z postrzeganiem ich poprzez pryzmat funkcji rolniczych (na podstawie m.in.: Bański 2006; Stanny 2014; Wójcik 2012). Skutkowało to tym, że obszary wiejskie uznawano za strefę jedynie produkcyjną, podporządkowaną obszarom miejskim, którym to powinna dostarczać żywności. Wyrazem zależności przestrzennych i funkcjonalnych między obszarami wiejskimi a miejskimi była natomiast koncepcja funkcji żywicielskiej wsi (Zgliński 1994). Nie dziwi zatem taki, a nie inny wymiar działań z zakresu odnowy wsi w tym okresie, zwłaszcza mając na uwadze skalę i rolę procesów urbanizacyjnych w miastach i ich rolę w okresie dynamicznego wzrostu gospodarczego, jaki miał miejsce w drugiej połowie XX w.

Współcześnie ocenia się, że takie wąskie rozumienie odnowy obszarów wiejskich było dalece niewystarczające, wręcz sprzeczne z jej dzisiejszym rozumieniem oraz że podejście to wyrządziło ogromne szkody w tradycyjnej architekturze wiejskiej, a także osłabiło tkankę społeczną wsi (Wilczyński i Idziak 2013). Można wysnuć wniosek, że programowanie pewnych mechanizmów, takich jak na przykład odnowa wsi, to w perspektywie kilku dziesięcioleci proces uczenia się. Proces ten odzwierciedlał również dochodzenie do obecnego stanu wiedzy na temat rozwoju obszarów wiejskich i czynników istotnych na poziomie lokalnym. Obecnie zaniechano przecież postrzegania obszarów wiejskich poprzez pryzmat jedynie rolnictwa. Zarówno koncepcje naukowe, jak i działania praktyczne korespondować musiały z przemianami obszarów wiejskich - mającymi miejsce zarówno spontanicznie, jak i w odpowiedzi na szersze, globalne procesy rozwojowe.

Drugim historycznym etapem odnowy wsi niemieckiej była odnowa fasad (lata 1975-1994). Częściowo miała ona „naprawić” negatywne skutki modernizacji obszarów wiejskich poprzez przywrócenie wsi jej tradycyjnego wyglądu i ładu oraz ich kultywowanie. Wówczas po raz pierwszy dostrzeżono także, że aby poprawić warunki życia ludności wiejskiej, należy zadbać o alternatywne, w domyśle pozarolnicze, miejsca pracy (Wilson 1999; Wilczyński i Idziak 2013). Istotne, że taki sposób myślenia o wiejskiej gospodarce wciąż jest (częściowo) obecny w przedsięwzięciach z zakresu odnowy wsi i wynika z założeń paradygmatu wielofunkcyjnego rozwoju obszarów wiejskich.

Jak twierdził J. Kostrowicki (1983), badania obszaru wiejskiego jako przestrzeni wielofunkcyjnej były przede wszystkim poszerzeniem dotychczasowego pola badań o funkcje inne niż rolnictwo. W związku z powyższym, „próba nowej interpretacji przemian obszarów wiejskich opierała się na przejściu od identyfikacji systemu rolniczego użytkowania ziemi do rozpoznania wielofunkcyjnego wykorzystania wiejskiej przestrzeni" (Wójcik 2012, s. 148). Sama koncepcja jest zatem wyrazem dostrzeżenia, że obszary wiejskie nie są obszarami monofunkcyjnymi. Współcześnie wielofunkcyjny rozwój obszarów wiejskich uznawany jest już za „tradycyjne” pole badawcze geografii wsi (Woods 2009; Wójcik 2012). Przyjęcie koncepcji obszaru wiejskiego jako przestrzeni wielofunkcyjnej jest także pewnym punktem wyjścia do badań zróżnicowania przestrzennego terenów wiejskich (Wójcik 2012) oraz współczesnych czynników ich rozwoju, takich jak: przedsiębiorczość i turystyka wiejska, alternatywne źródła dochodów ludności wiejskiej, infrastruktura techniczna, pozyskiwanie i wykorzystywanie funduszy Unii Europejskiej. Warto zwrócić uwagę na wyraźną zbieżność między celami programowymi rozwoju obszarów wiejskich (np. różnicowanie w kierunku prowadzenia działalności nierolniczej), przedmiotami 
dociekań naukowych (np. funkcje obszarów wiejskich) i przyjętymi kierunkami działań z zakresu odnowy (np. podniesienie jakości życia mieszkańców poprzez zapewnienie nowych miejsc pracy), co wyraża synergię postrzegania obszarów wiejskich jako obszarów posiadających własną w tym zakresie specyfikę na różnych płaszczyznach - teoretycznej i praktycznej. Jednocześnie należy stwierdzić, że paradygmat wielofunkcyjnego rozwoju wsi skupia się głównie na uzyskaniu ekonomicznych efektów. Przeciwstawnym dla niego jest wspomniany wcześniej paradygmat rewitalizacyjny, który włącza aspekty społeczne w nurt rozważań nad rozwojem obszarów wiejskich. Wieś ma być przede wszystkim przestrzenią życia jej mieszkańców. Takie myślenie o obszarach wiejskich rozwijało się wraz z ujawnieniem znaczenia społecznych aspektów życia na wsi i rosnącym zainteresowaniem nimi. Stąd w połowie lat 90. XX w. coraz mocniej zaczęto akcentować niematerialny wymiar odnowy wsi. Działania z tego zakresu skupiły się wokół nowych zasad, do których można zaliczyć: podstawowe znaczenie rozwoju osobowości mieszkańców i ich wykorzystywania dla dobra całej społeczności, włączenie mieszkańców wsi w spotkania poświęcone tworzeniu planów i projektów (Mayer 1997). Podkreślano także, że szansą wsi jest sam fakt bycia wsią, przestrzenią odmienną od przestrzeni miejskiej (Wilczyński i Idziak 2013), a więc zerwano z postrzeganiem tego, co miejskie, jako „lepsze” i za takie, do jakiego należy dążyć.

W dyskursie naukowym nad rozwojem, w tym obszarów wiejskich, ten społeczny sposób myślenia wyrażają choćby koncepcje kapitału społecznego, podejścia partycypacyjnego, partnerstw czy społeczeństwa obywatelskiego. Odwołując się do prac polskich badaczy, kapitał społeczny jako zasób obszarów wiejskich został przedstawiony m.in. przez I. Bukrabę-Rylską (2011), W. Goszczyńskiego (2008), M. Thlona (2015) i K. Zajdę (2011). Każdorazowo oceniano go jako jeden z kluczowych czynników powodzenia przedsięwzięć o charakterze lokalnym, a także przedsięwzięć wykraczającym poza fizycznie mierzalne projekty infrastrukturalne. Kapitał ten istotny jest także dla budowy partnerstw, w tym na rzecz odnowy wsi. Ich rolę potwierdzają przede wszystkim badania przeprowadzone w Europie Zachodniej (McArdle 2012; McLachlan i Arden 2009; Osborne, i in. 2004; Osborne i in. 2006). Rolę partycypacji natomiast uwypukla się nie tylko w samej odnowie wsi (Huttner 2013; Mayer 1997), lecz także w rozwoju obszarów wiejskich (Oakley 1991) i rozwoju w ogóle (White 2011). Z kolei rola społeczeństwa obywatelskiego w kształtowaniu odnowy wsi została ukazana przez H. Magela (2000). Wraz z pojawieniem się tego typu prac rosło znaczenie społecznych aspektów rozwoju. Jednocześnie wieś, jako przedmiot dociekań naukowych, doczekała się własnych - również odmiennych od miasta - teorii.

Ostatnim etapem odnowy wsi jest zrównoważony rozwój i tworzenie wiosek tematycznych, trwający od początku obecnego stulecia (Wilczyński i Idziak 2013). Już sama nazwa tego etapu wskazuje na wyraźną inspirację koncepcją rozwoju zrównoważonego. Należy podkreślić, że działania w tym nurcie niejako nakładają się na dotychczas prowadzone. Nie zaprzestano więc postrzegać odnowy wsi jako szansy na dywersyfikację miejsc pracy ludności wiejskiej oraz sposobu na aktywizację społeczeństwa. Wioski tematyczne są, zdaniem W. Idziaka (2008, s. 3), wyrazem zastosowania sposobu myślenia o rozwoju zrównoważonym na wsi. „Wieś tematyczna to taka wieś, której rozwój podporządkowany jest jakiemuś jednemu pomysłowi [...]. Temat bierze się zwykle z tego, co dla wsi jest charakterystyczne [...] ". Specyfika wsi wydobyta i manifestowana pewnym pomysłem na jej rozwój, prowadzi do dyskusji na temat unikalności zasobów [patrz rozdział dot. zasobów lokalnych w tym opracowaniu]. 
Zasadniczo komplementarność „interesów” gospodarczych, ludzkich i środowiska naturalnego oraz równowaga między nimi, uwypuklone w zasadach rozwoju zrównoważonego (Agenda 21 1993), znalazły swoje przełożenie w tym czasie w zasadach odnowy wsi - wieś traktuje się jako zintegrowany organizm, gdzie nie można i nie należy oddzielać „twardych” czynników jej rozwoju od „miękkich”. W obu grupach należy poszukiwać szans na ożywienie społeczne i gospodarcze obszaru. Podobnego zdania jest T.K. Marsden (2003, 2006), który podkreśla, że współczesne przemiany obszarów wiejskich mogą być zrozumiane poprzez próbę szerszego ujęcia ich rozwoju, który nie sprowadza się jedynie do modernizacji czy industrializacji (mechanizacji).

W studiach wiejskich zagadnienie to było szeroko dyskutowane już na początku lat 80. XX w. (opis problematyki rozwoju zrównoważonego na obszarach wiejskich prezentował już M. Pacione w 1984 r.). W polityce Unii Europejskiej śmiało zaakcentowano je dopiero pod koniec tamtego dziesięciolecia (CEC 1988; OECD 1989; Potter 1998). Na forum międzynarodowym zrównoważony rozwój pojawił się w podobnym czasie (Brudtland Commission 1987). Na początku lat 90. po szczycie klimatycznym w Rio de Janerio opublikowano raport Agenda 21 (1993), szeroko prezentujący ideę zrównoważonego rozwoju i zawierający wyzwania, jakie niesie dla ludzkości XXI wiek. Współcześnie konieczność realizacji działań zrównoważonych, identyfikowana i wskazywana jest we właściwie każdym dokumencie programowym, w tym także - w odniesieniu do obszarów wiejskich - w Programie Rozwoju Obszarów Wiejskich. Nie ulega więc wątpliwości, że zmiany, jakie zachodziły na wsi decydowały o tym, w jaki sposób i poprzez pryzmat jakich wartości postrzegano jej rozwój, w tym w kontekście naukowym. To z kolei decydowało, jak kształtowano odnowę wsi - na poziomie lokalnym i w sposób oddolny.

\section{Cechy odnowy wsi a zmiana sposobu postrzegania rozwoju obszarów wiejskich}

Przechodząc tak wyraźną ewolucję, odnowa wsi posiadała zmienny zestaw cech, który ukonstytuował się w ostatnich jej etapach, pod wpływem koncepcji rozwojowych, z których czerpie i którym podlega. Zalicza się do nich:

- bazowanie na lokalnym, tradycyjnym kapitale materialnym (wyrażonym np. obecnością wiejskiej tkanki architektonicznej i układu osadniczego) i wartościach niematerialnych wsi (wyrażonymi np. kultywowaniem tradycyjnych, regionalnych obyczajów czy przejawami folkloru),

- włączenie społeczności lokalnych w rozwój społeczno-gospodarczy i przedkładanie budowy kapitału społecznego nad budowę kapitału fizycznego,

- wzmocnienie wspólnoty lokalnej (jako próba przeciwstawienia się atomizacji społeczeństwa, która ma miejsce nie tylko w przestrzeni miejskiej),

- działanie na rzecz poprawy jakości życia mieszkańców wsi,

- rozwój wewnętrzny obszaru wraz z rewitalizacją jego zabudowy tak, by wykorzystać potencjał własny wsi,

- innowacyjność (na tle wypartego już rolniczo-industrialnego definiowania charakteru podejmowanych działań).

Wymienione cechy nawiązują do współczesnego postrzegania rozwoju wsi, który to obrał zdecydowanie (neo)endogeniczny kierunek. Warto odwołać się do dwóch celnych podsumowań zmian, które zaszły w postrzeganiu wsi i jej rozwoju w kontekście spe- 
cyfiki i znaczenia zasobu w rozwoju danego układu lokalnego. Pierwszą ilustrację stanowi zestawienie dwóch modeli percepcji przestrzeni wiejskiej: modelu rolniczego i modelu rozwojowego obszarów wiejskich na trzech płaszczyznach: aktorów, cech gospodarki kształtujących funkcje obszarów wiejskich i sił decydujących o kondycji ekonomicznej obszarów wiejskich (Baldock i in. 2001; tab. 1). W modelu rolniczym kluczową rolę odgrywali rolnicy, jako główni aktorzy sceny wiejskiej, od których aktywności zależała witalność obszarów wiejskich i rolnictwo jako główna funkcja wsi. W modelu rozwojowym zdecydowanie poszerzono pole widzenia - aktorzy reprezentują różne środowiska, podobnie różne są funkcje obszarów wiejskich, a kondycja sektora rolniczego nie musi przekładać się na kondycję wsi. W odnowie wsi podobna zmiana sposobu myślenia miała miejsce, gdy zaczęto odchodzić od modernizacyjnego jej paradygmatu.

Tabela 1. Jeden wiejski świat, dwie percepcje

\begin{tabular}{|l|l|}
\hline \multicolumn{1}{|c|}{ Model rolniczy } & \multicolumn{1}{|c|}{ Model rozwoju obszarów wiejskich } \\
\hline Interesy rolników są tożsame z interesem wiejskim & $\begin{array}{l}\text { Lokalni aktorzy reprezentują szeroki zakres interesów } \\
\text { zgodnie z ich społeczną przynależnością i statusem } \\
\text { ekonomicznym } \\
\text { Wielofunkcyjność obszarów wiejskich zależy od we- } \\
\begin{array}{l}\text { Wielofunkcyjność obszarów wiejskich jako rezultat } \\
\text { tradycyjnego rolnictwa }\end{array}\end{array}$ \\
$\begin{array}{l}\text { Witalność obszarów wiejskich zależna od aktywności } \\
\text { rolników: ekonomicznej i kulturowej }\end{array}$ & $\begin{array}{l}\text { Konkurencyjny sektor rolniczy nie zawsze jest warun- } \\
\text { kiem wstępnym witalności obszarów wiejskich }\end{array}$ \\
\hline
\end{tabular}

Źródło: D. Baldock i in. (2001, s. 28) [tłumaczenie - autorzy].

Jak wspomniano, współcześnie uwaga badaczy koncentruje się na endogenicznym potencjale wsi. Przejście z koncepcji egzogenicznej do endogenicznej wydaje się na tyle oczywiste i na tyle posługuje się tym drugim pojęciem wręcz sloganowo, że można dostrzec brak pewnej refleksji dotyczącej aspektów tego przejścia (tab. 2).

Tabela 2. Modele rozwoju obszarów wiejskich

\begin{tabular}{|c|c|c|}
\hline & Rozwój egzogeniczny & Rozwój endogeniczny \\
\hline Kluczowa zasada & $\begin{array}{l}\text { Ekonomiczne efekty skali } \\
\text { i koncentracji }\end{array}$ & $\begin{array}{l}\text { Włączanie lokalnych zasobów dla } \\
\text { potrzeb rozwoju zrównoważonego }\end{array}$ \\
\hline Siła napędowa & $\begin{array}{l}\text { Miejskie bieguny wzrostu (czynniki } \\
\text { zewnętrzne względem obszarów } \\
\text { wiejskich) }\end{array}$ & Inicjatywy i przedsięwzięcia lokalne \\
\hline Funkcja obszarów wiejskich & $\begin{array}{l}\text { Zapewnienie żywności i podstawo- } \\
\text { wych produktów dla rozwijających się } \\
\text { gospodarek miejskich }\end{array}$ & $\begin{array}{l}\text { Gospodarki oparte na zróżnicowa- } \\
\text { nych usługach }\end{array}$ \\
\hline $\begin{array}{l}\text { Główny problem (bariera) } \\
\text { rozwoju obszarów wiejskich }\end{array}$ & Niska produktywność i peryferyjność & $\begin{array}{l}\text { Ograniczony potencjał obszarów/ } \\
\text { grup do uczestniczenia w procesach } \\
\text { gospodarczych }\end{array}$ \\
\hline $\begin{array}{l}\text { Obszar zainteresowania } \\
\text { rozwoju obszarów wiejskich }\end{array}$ & $\begin{array}{l}\text { Modernizacja rolnictwa, mobilizacja } \\
\text { kapitału i siły roboczej }\end{array}$ & $\begin{array}{l}\text { Budowanie kapitału (umiejętności, } \\
\text { instytucje, infrastruktura) zapobiega- } \\
\text { jącemu wykluczeniu }\end{array}$ \\
\hline
\end{tabular}

Źródło: N. Ward i in. (2005, s. 4) [tłumaczenie - autorzy].

Odejście od postrzegania czynników zewnętrznych jako decydujących o rozwoju obszarów wiejskich znacząco zmieniło percepcję samej wsi. Za kluczową zasadę N. Ward i zespół (2005) uznają włączenie lokalnych zasobów w procesy rozwoju. Rozwój napędza- 
ny jest przedsięwzięciami o charakterze oddolnym, co z jednej strony odrzuca tezę, że kluczowe jest występowanie miejskich biegunów wzrostu, a z drugiej odpowiada na krytykę dotyczącą niedostrzegania roli czynników lokalnych. Co zostało wspomniane wcześniej, przestrzeń wiejska jest przestrzenią funkcjonalnie zróżnicowaną. Z kolei problemem (barierą) rozwoju obszarów wiejskich nie jest ich niska produktywność i peryferyjność, a niski naturalny ich potencjał do włączenia - tak wybranych obszarów, jak i grup współuczestniczących - do procesów rozwojowych. Odpowiedzią na to wyzwanie jest wielowymiarowe wzmacnianie kapitału społecznego wsi, gdzie podkreśla się m.in. rolę instytucji. Uczestnictwo wsi w szerszym spektrum procesów rozwojowych jest zatem warunkiem jej rozwoju wewnętrznego. Generalnie należy także stwierdzić, że wraz z ujawnieniem roli potencjału endogenicznego wsi zaczęto doceniać ten potencjał także w sferze społecznej.

Podobne przejście, które cechuje się coraz bardziej holistycznym ujmowaniem problematyki rozwoju obszarów wiejskich, w odnowie wsi odnajdujemy w dwu jej momentach czasowych. Wówczas, gdy nakreślono jej społeczno-duchowe pryncypia oraz gdy zaczęto postulować wiejskość jako walor sam w sobie.

\section{Rozwój wsi inny niż neoendogeniczny?}

W dobie dynamicznych zmian przestrzeni wiejskiej, na skutek doinwestowania i dokapitalizowania z wykorzystaniem funduszy Unii Europejskiej, pojęcie rozwoju neoendogenicznego wydaje się wysoce istotne. Zestawia ono bowiem potencjał własny obszarów wiejskich z wachlarzem zewnętrznych instrumentów wsparcia czy też wykorzystania tego potencjału. Wydaje się, że w obecnych warunkach finansowania działań prorozwojowych tak naprawdę trudno mówić o innym typie rozwoju niż neoendogeniczny. Termin ten został zaproponowany przez Ch. Raya (2001) jako wyraz dostrzeżenia czynników ekstra-lokalnych i przekonania, że obszary wiejskie mogą same, z wykorzystaniem swojego potencjału, kształtować swoją przyszłość. Wtórują mu choćby G. Bosworth i J. Atterton (2012), którzy dodają, że istotą są relacje między różnymi formami potencjału, mianowicie: kulturowego, społecznego, edukacyjnego i ekonomicznego. Centrum uwagi stanowi zatem zasób na poziomie lokalnym. O kształtowaniu kierunków rozwoju i szansach na pozytywny rozwój decyduje jednocześnie nie tylko poziom tego zasobu, ale także jego specyfika wyrażona tymi współzależnościami.

Ch. Ray (2010) wskazuje także, że rozwój oparty na zasobach lokalnych może być animowany z trzech potencjalnych kierunków, osobno lub równocześnie. Po pierwsze, przez aktorów lokalnych. Po drugie, odgórnie, przez rządy krajowe i/lub programy europejskie. Po trzecie, z poziomu pośredniego, w szczególności przez organizacje pozarządowe, których spektrum działania łączy myślenie globalne z działaniem lokalnym. W kontekście obszarów wiejskich w Polsce właśnie ten ostatni kierunek wydaje się niezwykle ważny - liczne prace ukazują rolę trzeciego sektora, zwłaszcza Lokalnych Grup Działania, w kierowaniu rozwojem obszarów wiejskich (np. Borowska 2009; Brodziński i Brodzińska 2014; Iwańska 2009; Knieć 2012; Ocena funkcjonowania lokalnych grup działania...2012; Pałka 2014).

W literaturze polskiej celnej interpretacji dostarcza np. M. Michalewska-Pawlak (2013, s. 54): „Podejście neoendogeniczne jest zmodyfikowaną wersją podejścia endogennego, które podkreśla, że rozwój lokalny powinien opierać się na czynnikach wewnętrznych, specyficznych dla danego obszaru, oraz na potencjale i zasobach wykorzystywanych 
przez społeczność lokalną". Dodaje także, że potencjał ten wypływa z lokalnych uwarunkowań oraz że powinien być wykorzystywany zgodnie z lokalnymi potrzebami, w tym za pomocą instrumentów zewnętrznych. Zasób lokalny funkcjonuje zatem w pewnym otoczeniu, które stanowi także w części społeczność lokalna, a także kształtuje to otoczenie.

Podobne instrumenty finansowe posiada odnowa wsi. W nawiązaniu do przedstawionych we wstępie poziomów odnowy wsi, zewnętrzne - względem podmiotu podejmującego lub uczestniczącego w działaniach, tj. sołectwa lub gminy - źródła finansowania są typowe dla działań na poziomie regionalnym (wewnątrz kraju), krajowym i europejskim. Działania z zakresu odnowy wsi, które niewątpliwie mają charakter lokalny i społeczny, wyraźnie więc wpisują się w te koncepcje rozwoju obszarów wiejskich. Stąd faktycznie odnowę wsi można traktować jako pewien sposób kształtowania tego rozwoju lub myślenia o nim.

\section{Zasoby lokalne w rozwoju i odnowie wsi - wybrane zagadnienia}

Pojęcie zasobu, nie może być inaczej, ma wiele znaczeń. Naszym celem na tym etapie pracy nie jest jednoznaczne określenie, czym jest zasób, czym jest zasób lokalny, a raczej przybliżenie różnych, wybranych sposobów ich rozumienia, w tym w badaniach naukowych. Zacząć należy od tego, że słowo to występuje zupełnie pospolicie. Internetowy Słownik Języka Polskiego PWN wskazuje, że zasób to „pewna ilość czegoś nagromadzona w celu wykorzystania w przyszłości” lub „posiadane doświadczenie, wiedza, umiejętności”. Już w powszechnym użyciu dochodzi do oczywistego rozgraniczenia zasobu na materialny i niematerialny. Z tym samym mamy do czynienia na gruncie specjalistycznym, w zasadzie niezależnie od dyscypliny naukowej.

Zasoby, niezależnie jak rozumieć to pojęcie, są zlokalizowane nierównomiernie, co jest oczywiste. Nieuchronne jest zatem postrzeganie ich poprzez pryzmat rozmieszczenia, tj. w ujęciu regionalnym i lokalnym. W gospodarczym kontekście, „zasoby to rzeczy bądź wartości intelektualne wykorzystywane do produkcji dóbr i usług w regionie" (Strzelecki, 2008, s. 79). M. Stanny (2013, s. 214) uważa, że „[...] zasoby lokalne uznać można za podstawowe czynniki rozwoju danego obszaru”. „Danego”, tzn. w domyśle określonego czy wydzielonego wycinka przestrzeni. Można wnioskować na tej podstawie, że lokalne wykorzystanie tych zasobów decyduje o rozwoju w tej skali, co nawiązuje do (neo)endogenicznego postulatu rozwojowego.

Rozwój lokalny, jak już zostało powiedziane, zachodzi w pewnych układach terytorialnych, cechujących się własną autonomią, która wyznacza zasięg tego układu. Każdy układ w skali lokalnej będzie wyróżniał się niepowtarzalnością zjawisk i procesów w nim zachodzących. Jeżeli te uwarunkowania wiązać z zasobami lokalnymi i ich rozmieszczeniem, to ważne wydaje się podjęcie kwestii specyfiki zasobów. Dość intuicyjny jest podział na zasoby pospolite i unikatowe (pojęcia te rzecz jasna nie opisują dychotomicznego podziału, a są krańcowymi przymiotnikami opisującymi pewną skalę). W zależności od przypisanych im cech mogą być różnie wykorzystywane - dotyczy to przykładów in plus i in minus. Różne są zatem ścieżki ich wykorzystania, czy też, jak nazywają to S. Michalska i K. Zajda (2011, s. 124) trajektorie użytkowania:

- specyficzne: zasoby unikatowe dla danego obszaru są wykorzystywane w sposób niestandardowy, w związku z lokalną tradycją, specyfiką, 
- ogólne: zasoby występujące powszechnie są wykorzystywane w sposób standardowy,

- ogólne z rysami specyficznymi: zasoby powszechne, typowe dla wielu obszarów są wykorzystywane w sposób niestandardowy, unikatowy, związany z lokalną specyfiką,

- banalizujące: zasoby unikatowe dla danego obszaru są wykorzystywane w sposób typowy, standardowy bez nawiązania do ich specyfiki.

Zanim jednak obiekty (materialne lub niematerialne) zostaną wykorzystane i staną się zasobem, muszą uprzednio zostać zidentyfikowane jako w pewien sposób wyjątkowe - tzn. musi dokonać się ich waloryzacja. W związku z tym na to, czy dany obiekt stanie się zasobem wpływa nie tylko jego obiektywna wartość, ale także jego postrzeganie (Michalska i Zajda 2011).

Spojrzenie na zasoby lokalne poprzez pryzmat nie tylko specyfiki ich samych, ale także specyfiki ich wykorzystania jest konieczne, jeśli chcemy powiązać zasoby lokalne z odnową wsi. Wynika to z faktu, że to lokalna społeczność, jako główny aktor odnowy wsi, przesądza o tym, w jaki sposób wykorzysta zasób własnej wsi, który jest odmiennym od zasobów innych wsi. W celu pozyskania wiedzy na temat, w jaki sposób zasób jest wykorzystywany przez liderów działań na rzecz rozwoju wsi, dokonano eksperckiego przeglądu literatury przedmiotu, dotyczącej działań z zakresu lub na rzecz odnowy wsi, prezentującej poza pierwiastkiem teoretycznym badania empiryczne lub nawiązanie do nich. O zasobach lokalnych, w kontekście szeroko rozumianej odnowy wsi pisze się w pracach poświęconych m.in.:

- kapitałowi społecznemu w odnowie i rozwoju wsi (np. Damyanovic i Reinwald 2014; Murray i Dunn 1995), migracjom w kontekście budowy tego kapitału (np. Stockdale 2005, 2006), i partnerstwom w odnowie i w rozwoju lokalnym (np. Cabus i Van Haverbeke 2003; McArdle 2012),

- turystyce wiejskiej i jej roli w ekonomicznej odnowie wsi (np. Everett i Aitchison 2008; Hashimoto i Telfer 2010; Lane i Kastenholz 2015; Su 2011, 2013),

- dziedzictwu kulturowemu i tkance urbanistycznej w odnowie wsi (np. Fonseca i Ramos 2012; Hudeckova i Sevcikova 2007; Silva 2012),

- kreowaniu nowego zasobu w celu odnowy wsi (np. Hong i Lee 2015).

Oczywiście powyższe przykłady nie wyczerpują listy prac na ten temat. Ukazują jednak kontekst, w jakim rozpatruje się, w dość ogólnym zarysie, wykorzystanie zasobu lokalnego w rozwoju wsi, gdzie kierujący nim odczują pewną potrzebę „odnowy”, czy to w wymiarze ekonomicznym, przestrzennym, czy społecznym. Wskazują też, co stanowi lub może stanowić przestrzeń wykorzystania tych zasobów.

W każdym przypadku zasób ten podlega odpowiedniej trajektorii wykorzystania. Nie można mówić o powodzeniu wsi, jeżeli jej zasób nie zostanie wykorzystany w pewien określony sposób - rozpoznany, świadomy, przeanalizowany lub nawet skonceptualizowany i ujęty w formie strategii. Podobnie nie można mówić o powodzeniu odnowy, jeżeli nie jest ona przeprowadzona według pewnego pomysłu na wieś (choć nie jest to jedyny czynnik decydujący o powodzeniu; do pozostałych należy zaliczyć choćby zaangażowanie mieszkańców i obecność silnego lidera działań lokalnych). Pomysł ten, tj. specyficzne trajektorie wykorzystania zasobów, jest wartością dodaną wówczas, gdy zasób nie posiada cech unikatowego. Cytując za K. Zajdą (2013, s. 92): „dostrzeżenie zasobu nie przesądza

o sposobie jego wykorzystania. Zasoby unikatowe dla danego obszaru mogą być wy- 
korzystywane w sposób podkreślający ich wyjątkowość. Mogą również zostać zbanalizowane, czyli użyte w sposób, który owej wyjątkowości zaprzecza. Zasoby występujące dość powszechnie można z kolei wykorzystać w sposób niestandardowy, nawiązujący do specyfiki danego obszaru".

\section{Podsumowanie}

Odnowa wsi, choć szeroko czerpiąca z różnych koncepcji naukowych, rozumiana powinna być przede wszystkim poprzez pryzmat realizowanych działań praktycznych i ich efektów w przestrzeni wiejskiej, tj. pewnej ilościowej i jakościowej zmiany. Współcześnie stanowi ona nie tylko istotny komponent działań na rzecz szeroko rozumianego rozwoju obszarów wiejskich, ale i wynika z założeń tegoż rozwoju. Ściślej ujmując, odnowa wsi wprost nawiązuje do paradygmatu rewitalizacyjnego. Nie oznacza to jednak, że związek ten istniał od samego początku realizacji działań z zakresu odnowy. W historii realizacji odnowy wsi, zwłaszcza w Niemczech, znajdujemy bowiem inspiracje także innymi paradygmatami/koncepcjami rozwoju obszarów wiejskich. Można powiedzieć, że odnowa wsi przeszła długą drogę, począwszy od działań modernizacyjnych, przez działania na rzecz rozwoju i aktywizacji społeczności, skończywszy na działaniach wpisujących się w założenia rozwoju zrównoważonego, przy czym dodatkowo te typy działań nakładały się na siebie w czasie.

Zmiany w postrzeganiu wsi, a głównie odejście od postrzegania jej poprzez pryzmat rolnictwa, wpłynęły na zmiany w koncepcjach rozwoju obszarów wiejskich. Jednocześnie wraz z nowymi koncepcjami zmianom nie podlegała jedynie sama odnowa wsi. Zmieniało się także postrzeganie roli zasobów obszaru. Obecnie za kluczowe w rozwoju wsi, ale także i szerzej - w rozwoju regionalnym, uważa się zasoby lokalne danego obszaru. O ich wykorzystaniu powinna decydować lokalna społeczność, mając do dyspozycji instrumenty zewnętrzne. Odnowa wsi opiera się właśnie na zasobach lokalnych, a jednocześnie je wzmacnia. Można powiedzieć, że odnowa wsi to odnowa jej zasobów. Z jednej strony specyfika zasobu warunkuje sposób realizacji odnowy wsi, z drugiej zaś zdiagnozowany, uruchomiony i wykorzystany zasób staje się z kolei czynnikiem jego rozwoju. Potwierdza to ścisłe związki i współzależności między odnową wsi, zasobem i rozwojem (obszarów wiejskich lub regionalnym).

W kontekście relacji między odnową wsi, zasobami lokalnymi i rozwojem obszarów wiejskich warto zadać także kilka pytań. Po pierwsze, jeżeli odnowa wsi ma szansę stać się pewnym sposobem myślenia o rozwoju obszarów wiejskich, z poszanowaniem ich tradycyjnych wartości i zasobów, to niezwłocznym pytaniem jest, na ile tożsame jest powodzenie w rozwoju społeczno-gospodarczym z powodzeniem realizacji odnowy wsi. Zbliżone charakterem są dwa kolejne pytania. Co jest miarą powodzenia odnowy wsi i czy jest to stopień wykorzystania zasobów lokalnych? Czy i w jaki sposób wzmacniać lokalne zasoby wsi oraz czy wspierać kreowanie nowych?

Po drugie, należy zadać sobie pytanie o same zasoby wsi, ich dostrzeżenie, wartościowania i sposób wykorzystania w celu odnowy - zarówno zasobu, jak i wsi. W tak rozumianej odnowie wsi już sam fakt nierównomiernego występowania zasobów będzie decydował o różnej jej specyfice. Na to nakłada się trajektoria ich wykorzystania, o której decyduje społeczność lokalna. Są to zatem dwa czynniki, które decydują o sposobie re- 
alizacji odnowy wsi rozumianej jako odnowa zasobów wsi. Ważnym pytaniem jest więc, w jaki sposób uczynić obiekt zasobem w oczach mieszkańców wsi i jak wykorzystać konkretny zasób. Przytoczone dylematy to oczywiście jedynie wybrane spośród tych, które dotyczą odnowy wsi, jednak niezwykle istotne w perspektywie jej związków z zasobami i jej rozwojem.

Nie ulega wątpliwości, że wieś posiada swoją własną tożsamość i odrębność. Wyraża się to choćby specjalizacją naukową badaczy zajmujących się takimi zagadnieniami, jak rozwój gospodarczy, kapitał społeczny czy wreszcie odnowa wsi. Dostrzega się także coraz większą dynamikę przemian przestrzeni wiejskiej, co z kolei odzwierciedla się w różnicowaniu działań na rzecz rozwoju obszarów wiejskich. W ostatnich dekadach wieś zyskuje także na uznaniu ze strony jej mieszkańców. W konsekwencji tych procesów pojawiają się pewne idee czy metody jej rozwoju lub ,jedynie” zachowania jej specyfiki. Coraz istotniejszym przykładem takiego sposobu myślenia jest odnowa wsi, o której powodzeniu w Polsce - ze względu na różny poziom regionalnego zaawansowania i brak rozwiązań organizacyjnych - na razie trudno orzekać.

\section{Literatura}

Agenda 21, 1993, United Nations, United States.

Baldock D., Dwyer J., Lowe P., Petersen J.-E., Ward N., 2001, The Nature Of Rural Development: Towards A Sustainable Integrated Rural Policy In Europe. A Ten-Nation Scoping Study for WWF and the GB Countryside Agencies, Countryside Agency, Countryside Council for Wales, English Nature and Scottish Natural Heritage, IEEP.

Bański J., 2006, Geografia Polskiej Wsi, Polskie Wydawnictwo Ekonomiczne, Warszawa.

Borowska A., 2009, Lokalne grupy działania czynnikiem stymulujacym rozwój obszarów wiejskich w Polsce, Acta Scientarium Polonorum, Oeconomica 8, 4, s. 13-22.

Bosworth G., Atterton J., 2012, Entrepreneurial In-migration and Neoendogenous Rural Development, Rural Sociology, 77, 2, s. 254-279.

Brodziński Z., Brodzińska A., 2014, Sektor społeczny i jego rola w stymulowaniu rozwoju obszarów wiejskich, Roczniki Naukowe, Stowarzyszenie Ekonomistów Rolnictwa i Agrobiznesu, 16, 4, s. 52-56.

Brundtland Commission, 1987, Report of the World Commission on Environment and Development (Our Common Future), United Nations.

Bukraba-Rylska I., 2011, Kapitał społeczny polskiej wsi w świetle badań na programem Leader, [w:] I. Bukraba-Rylska (red.), Między interwencjq a interakcjq. Lokalne grupy działania w społecznościach wiejskich, Wydawnictwo Naukowe SCHOLAR, Warszawa, s. 12-33.

Cabus P., VanHaverbeke W., 2003, The Economics of Rural Areas in the Proximity of Urban Networks: Evidence from Flanders, Tijdshrift voor Economische en Sociale Geographie, 94, 2, s. $230-245$.

CEC, 1988, The Future of Rural Society, Commission of the European Council, Bruksela.

Chądzyński J., 2012, Nowe koncepcje regionu - w kierunku rozwoju lokalnego, [w:] J. Chądzyński, A. Nowakowska, Z. Przygodzki (red.), Region i jego rozwój w warunkach globalizacji, CeDeWu.pl Wydawnictwa Fachowe, s. 63-104.

Chigbu U.E., 2012, Village renewal as an instrument of rural development: Evidence from Weyarn, Germany, Community Development, 43, 2, s. 209-224. 
Chojnicki Z., 1999, Podstawy metodologiczne i teoretyczne geografii, Bogucki Wydawnictwo Naukowe, Poznań.

Damyanovic D., Reiwald F., 2014, The "Comprehensive Village Renewal Programme in Burgerland" as a Means of Strengthening the Social Capital in Rural Areas, European Countryside, 1, s. 18-35.

Dawkins C.J., 2003, Regional Development Theory: Conceptual Foundations, Classic Works, and Recent Developments, Journal of Planning Literature, 18, 2, s. 131-172.

Domański B., 2004, Krytyka pojęcia rozwoju a studia regionalne, Studia Regionalne i Lokalne, 2, 16, s. 7-23.

Everett S., Aitchison C., 2008, The Role of Food Tourism in Sustaining Regional Identity: A Case Study of Cornwall, South West England, Journal of Sustainable Tourism, 16, 2, s. 150-167.

Fonseca F.P., Ramos R.A.R., 2012, Heritage Tourism in Peripheral Areas: Development Strategies and Constraints, Tourism Geographies, 14, 3, s. 467-493.

Gorlach K., 2004, Rozwój obszarów wiejskich, [w:] K. Gorlach (red.), Socjologia obszarów wiejskich. Problemy i perspektywy, Wydawnictwo Naukowe SCHOLAR, Warszawa, s. 121-160.

Goszczyński W., 2008, Kształtowanie synergicznych form kapitału społecznego jako warunek prawidłowej aktywizacji społeczności lokalnych na przykładzie pilotażowego programu LEADER+, [w:] H. Podedworna, P. Ruszkowski (red.), Społeczne aspekty zrównoważonego rozwoju wsi w Polsce, Wydawnictwo Naukowe SCHOLAR, Warszawa, s. 102-122.

Grosse T.G., 2002, Przegląd koncepcji teoretycznych rozwoju regionalnego, Studia Regionalne i Lokalne, 1, 8, s. 25-48.

Hashshimoto A., Telfer D., 2010, Developing sustainable partnerships in rural tourism: the case of Oita, Japan, Journal of Policy Research in Tourism, Leisure and Events, 2, 2, s. 165-183.

Henkel G., 2000, Village renewal in German - Present and future of a successful program, Berichte Uber Landwirtschaft, supplement, s. 101-107.

Hong S.-G., Lee H.-M., 2015, Developing Gamcheon Cultural Village as a tourist destination through co-creation, Service Business, 9, s. 749-769.

Hudečková H., Ševčíková A., 2007, The renewal of the rural cultural heritage of the Czech Republic with the support of regional policy, Agricultural Economics, 53, 11, s. 505-512.

Huttner N., 2013, Entwicklung ländlicher Kommunen. Wenn Bürger Beteiligung ernst nehmen, Organisationsberat Superv Coach, 20, s. 23-34.

Idziak W., 2008, Wymyślić wieś od nowa. Wioski tematyczne, Alta Press, Koszalin.

Internetowy Słownik Języka Polskiego PWN: http://www.sjp.pwn.pl [25.05.2016].

Iwańska M., 2009, Rola organizacji pozarzqdowych w rozwoju obszarów wiejskich, Zagadnienia Doradztwa Rolniczego, 2, s. 62-71.

Kaleta A., 2007, Odnowa wsi z perspektywy historycznej, [w:] M. Kłodziński, M. Błąd, R. Wilczyński (red.), Odnowa wsi w integrujq̨cej się Europie, Problemy Rozwoju Wsi i Rolnictwa, IRWiR PAN, Warszawa, s. 77-86.

Kamiński R., 2007, Odnowa wsi i Leader: komplementarność metod rozwoju obszarów wiejskich, [w:] M. Kłodziński, M. Błąd, R. Wilczyński (red.), Odnowa wsi w integrujqcej się Europie, Problemy Rozwoju Wsi i Rolnictwa, IRWiR PAN, Warszawa, s. 165-180.

Knieć W., 2012, Wspólna Polityka Rolna a zrównoważony rozwój obszarów wiejskich Polski, Wydawnictwo Naukowe Uniwersytetu Mikołaja Kopernika, Toruń.

Kostrowicki J., 1983, Polska geografia rolnictwa. Mechanizmu rozwoju, Przegląd Geograficzny, 55, 3-4, s. 597-631.

Lane B., Kastenholz E., 2015, Rural tourism: the evolution of practice and research approaches - towards a new generation concept?, Journal of Sustainable Tourism, 23, 8-9, s. 1133-1156. 
Magel H., 1991, Europaische Aufgabe Dorf- und Landschaftsentwicklung. Aktuelle Anmerkungen zum Stellenwert und Weg der Landlichen Neuordnung in Bayern, Zeitschrift fur Vermessungswesen, 116, 8-9, s. 325-332.

Magel H., 2000, Village renewal - Model for self-initiative and future orientation, Zeitschrift fur Kulturtechnik und Landentwicklung, 41, 6, s. 274-278.

Marsden T.K., 2003, The Condition of Rural Sustainability, Van Gorcum, Assen.

Marsden T.K., 2006, The road towards sustainable rural development: issues of theory, policy and practice in a European context, [w:] P. Cloke, T.K. Marsden, P. Mooney (red.), Handbook of Rural Studies, SAGE Publications, London, Thousand Oaks, New Delhi, s. 201-212.

Mayer S., 1997, Citizen participation in village renewal - experiences from the preliminary phase, Munchener Geographische Hefte, 75, s. 103-126.

McArdle K., 2012, What makes a successful rural regeneration partnership? The views of successful partners and the importance of ethos for the community development professional, Community Development, 43, 3, s. 333-345.

McLachlan K., Arden C., 2009, Community Learning Projects: Transforming Post-Compulsory Education Provision in Rural Communities, Rural Society, 19, 2, s. 146-162.

Michalewska-Pawlak M., 2013, Priorytety i wyzwania polityki rozwoju obszarów wiejskich Unii Europejskiej, Oficyna Wydawnicza ASPRA, Warszawa.

Michalska S., Zajda K., 2011, Trajektorie wykorzystania zasobów lokalnych w procesie rozwoju partnerstw terytorialnych. Case study lokalnych grup działania "Dolina Karpia" oraz "Kraina Rawki", Wieś i Rolnictwo, 4, 153, s. 123-138.

Murray M., Dunn L., 1995, Capacity Building for Rural Development in the United States, Journal of Rural Studies, 1, 1, s. 89-97.

Ocena funkcjonowania lokalnych grup działania realizujqcych lokalna strategię rozwoju w ramach PROW 2007-2013. Raport końcowy, 2012, PSDB, Warszawa.

Oakley P., 1991, Projects with people: the practice of participation in rural development, International Labor Office, Geneva.

OECD, 1989, Agricultural and Environmental Policies. Opportunities for Integration, Paris.

Osborne S.P., Williamson A., Beattie R., 2004, Community involvement in rural regeneration partnerships: Exploring the rural dimension, Local Government Studies, 30, 2, s. 156-181.

Osborne S.P., Beattie R., Williamson A., 2006, The impact of local voluntary and community sector infrastructure on community involvement in rural regeneration partnerships, Public Money and Management, 26, 4, s. 235-242.

Pacione M., 1984, Rural Geography, Harper and Row, London.

Pałka E., 2014, Rola lokalnych grup działania w rozwoju obszarów wiejskich. Przykład województwa świętokrzyskiego, Studia i Materiały, Miscellanea Oeconomicae 18, 3, s. 189-203.

Potter C., 1998, Against the Grain: Agri-environmental Reform in the United States and the European Union, CAB International, Wallingford.

Ray Ch., 2001, Culture Economies: a perspective on local rural development in Europe, Centre for Rural Economy, University of Newcastle upon Tyne.

Schopen W., 2001, German Policy for an Integrated Rural Development, [w:] D. Virchow, J. von Braun (red.), Villages in the Future. Crops, jobs and livelihood, Springer-Verlag, Berlin, Heidelberg, s. 85-89.

Silva T., 2012, Built heritage-making and socioeconomic renewal in declining rural areas: evidence from Portugal, Etnográfica, 16, 3, s. 487-510.

Stanny M., 2013, Zasoby lokalne jako czynniki rozwoju obszarów wiejskich w Polsce, [w:] M. Stanny (red.), Przestrzenne zróżnicowanie rozwoju obszarów wiejskich w Polsce, IRWiR PAN, s. 213-262. 
Stanny M., 2014, Wieś, obszar wiejski, ludność wiejska - o problemach z ich definiowaniem. Wielowymiarowe spojrzenie, Wieś i Rolnictwo, 1, 162, s. 1-16.

Stockdale A., 2005, Incomers: Offering economic potential in rural England, Journal of the Royal Agricultural Society of England, 166, s. 1-5.

Stockdale A., 2006, Migration: Pre-requisite for rural economic regeneration?, Journal of Rural Studies, 22, s. 354-366.

Strzelecki Z., 2008, Polityka regionalna, [w:] Z. Strzelecki (red.), Gospodarka regionalna i lokalna, Wydawnictwo Naukowe PWN, Warszawa, s. 78-120.

Su B., 2011, Rural Tourism in China, Tourism Management, 32, s. 1438-1441.

Su B., 2013, Developing Rural Tourism: the PAT Program and "Nong jia le" Tourism in China, International Journal of Tourism Research, 15, s. 611-619.

Szewczuk A., 2011, Rozwój lokalny i regionalny - główne determinanty, [w:] A. Szewczuk, M. Kogut-Jaworska, M. Zioło (red.), Rozwój lokalny i regionalny. Teoria i praktyka, Wydawnictwo C.H. Beck, s. 13-88

Thlon M. (red.), 2015, Budowa kapitału społecznego do wykorzystania w procesie zarzadzania rozwojem kierowanym przez lokalnq społeczność, Warszawa.

Ustawa z dnia 9 października 2015 roku o rewitalizacji, Warszawa. Dostępne na: http://isap.sejm. gov.pl [26.05.2016].

Ward N., Atterton J., Kim T.-Y., Lowe P., Phillipson J., Thompson N., 2005, Universities, the Knowledge Economy and 'Neo-Endogenous Rural Development', Centre for Rural Economy Discussion Paper Series, 1, s. 1-15.

White S., 2011, Depoliticizing development: the uses and abuses of participation [w:] A. Cornwall (red.), The Participation Reader, Zed Books, London, s. 57-69.

Wilczyński R., 2003, Odnowa wsi perspektywq rozwoju obszarów wiejskich w Polsce, Fundacja Fundusz Współpracy - Program Agro-Info, Krajowe Centrum Doradztwa Rozwoju Rolnictwa i Obszarów Wiejskich Oddział w Poznaniu, Poznań.

Wilczyński R., Idziak W., 2013, Odnowa wsi. Przestrzeń, ludzie, działania, Fundacja Programów Pomocy dla Rolnictwa FAPA, Warszawa.

Wilson O.J., 1999, Village renewal and rural development in the former German Democratic Republic, GeoJournal, 46, s. 247-255.

Wolski O., 2016, Odnowy wsi jako przedmiot badań w niemieckich pracach naukowych. Geneza i ewolucja znaczenia, [w:] Ł. Sykała (red.), Odnowa wsi jako narzędzie rozwoju lokalnego. Ujęcie teoretyczne i praktyczne, Instytut Rozwoju Miast, Kraków (w trakcie publikacji).

Woods M., 2005, Rural Geography, Sage, London.

Woods M., 2009, Rural Geography [w:] R. Kitchin, N. Thrift (red.), International Encyclopedia of Human Geography, 9, Elsevier, Amsterdam, s. 429-441.

Wójcik M., 2012, Geografia wsi w Polsce. Studium zmiany podstaw teoretyczno-metodologicznych, Wydawnictwo Uniwersytetu Łódzkiego, Łódź.

Zajda K., 2011, Nowe formy kapitału społecznego wsi. Studium przypadku lokalnych grup działania z województwa łódzkiego, Wydawnictwo Uniwersytetu Łódzkiego, Łódź.

Zajda K., 2013, Innowacja w wiejskiej przedsiębiorczości. Studium przypadku działalności gospodarczej z obszaru doliny Pilicy, Studia Regionalne i Lokalne, 1, 51, s. 90-106.

Zgliński W., 1994, Kształtowanie się strefy żywicielskiej aglomeracji warszawskiej, Prace Geograficzne, 162 , s. 15-161. 


\section{Summary}

Village renewal is currently being more and more highlighted as an element of rural space changes, both in terms of practical and theoretical context. The way the village renewal has changed was conditioned by changing approaches to rural areas development. At the same time, the role of local resources in rural development concepts has been different and changed according to the concepts. The above-mentioned are overlaid by the issue of the use of local resources in village renewal actions. That issue has also been dynamic in the history of village renewal. There is no doubt that those three subjects (village renewal, rural development and local resources), strongly correspond to each other.

We have decided to undertake the description of these relations in order to systematise the state of art in the common ground for these three issues. The main aim of the paper was to present the embeddedness of village renewal in rural development paradigms, partly in regional/local development paradigms, and in other scientific concepts, as well as to present the role of local resources in village renewal processes over the years. The paper, based on literature review, is theoretical and open to further debate.

The considerations included in the paper indicate that village renewal bases on local resources and simultaneously strengthens them. Local resources are recognised as key in regional/local development. In the light of current scientific concepts, it is a local community who shall decide about the utilisation of these resources, which could use external instruments for this purpose. 